\title{
Hospital at Home, an innovative approach for Elderly care during the COVID-19 Pandemic
}

\section{Dr. MD Abu Bashar}

Assistant Professor, MMIMSR, MM Deemed University, Mullana, Ambala, Haryana, India

Corresponding Author: MD Abu Bashar, Assistant Professor, MMIMSR, MM Deemed University, Mullana, Ambala, Haryana, India.

Received date: January 17 2021; Accepted date: February 05, 2021; Published date: February 08, 2020

Citation: A Bashar. (2021) Hospital at Home, an innovative approach for Elderly care during the COVID-19 Pandemic. Clinical Research and Clinical Trials. 3(1); DOI: 10.31579/2693-4779/020

Copyright: Copyright (C) 2021, Abu Bashar. This is an open access article distributed under the Creative Commons Attribution License, which permits unrestricted use, distribution, and reproduction in any medium, provided the original work is properly cited.

\section{Abstract}

The COVID-19 pandemic has profoundly affected the elderly people (those aged 60 years or above as per the definition by the World Health Organization) who are found to have higher rates of infection and poorer health outcomes in this pandemic compared to other age groups $[1,2]$. Nevertheless, elderly adults, despite having a wide range of chronic illnesses, are experiencing critically inadequate access to care as healthcare organizations are emphasizing more on patients primarily affected by COVID-19 [3,4]. Furthermore, Elderly people remain most vulnerable in this pandemic as most of the nations do not have adequate preparedness to ensure acute and chronic geriatric care in public health emergencies $[4,5]$.

Keywords: COVID-19 pandemic; World Health Organization; public health emergencies

\section{Introduction}

Although community-based gerontological care may alleviate healthrelated problems of elderly people, such efforts may appear to be inadequate for acute exacerbation of chronic diseases or other clinical scenarios that cannot be avoided [6,7]. In these circumstances, visiting health centers may expose the older adults to corona virus, or other hospital acquired infections, which could be a perfect disaster leading to adverse health outcomes.

Hospital at Home (HAH) is a concept that emphasizes on providing active treatment in the home environment of a patient who would otherwise requires in-patient hospital care [8]. Such services, originating in the midtwentieth century, has been increasingly adopted by many healthcare organizations in the US, Canada, Netherlands, Australia, and the UK $[8,9]$. Under the HAH program, an emergency or community-level healthcare provider identifies a patient with a health problem and conducts an initial assessment using predetermined criteria to check if the patient needs hospitalization or if the HAH care can effectively fulfill the requirements of clinical care [9]. For understanding the concept of $\mathrm{HAH}$, suppose a patient requiring surgical intervention may need acute care through hospitalization, but the post-operative and follow-up care can be delivered through HAH. Clinical conditions prevalent in elderly adults, including congestive heart failure, chronic obstructive pulmonary disease, cellulitis, or community-acquired pneumonia can be effectively treated through $\mathrm{HAH}$. Once $\mathrm{HAH}$ is established, a healthcare team is assigned to ensure that the patient's home is transformed for providing hospital-grade care through scheduled visits by healthcare providers and coordinated care facilities on an emergency basis. As required, clinical and laboratory services can be delivered through $\mathrm{HAH}$ care and the patient can be discharged once a clinically stable health status is achieved [10]. The increasing adoption of $\mathrm{HAH}$ in recent years is informed by a wide range of advantages that includes lowering the demand for hospital beds, reducing operational costs of clinical care, and decreasing the risks of hospital-acquired infections [9]. However, there are several additional or collateral benefits for the elderly population who receive HAH. First, HAH offers hospital-level care at home environment, which can be desirable for older adults who prefer to receive clinical services in their regular environment and close contacts with their informal caregiver rather than institutionalized care $[8,9]$. Secondly, elderly people usually require long-term care for chronic conditions that usually does not require acute in-patient care. Such services can be organized within the scope of HAH. Thirdly, the autonomy and control over own health and associated decisions can be ensured within the home environment, which may contribute to better mental health and overall psycho social wellbeing in elderly peoples [11]. Last but not the least, in-patient care may provide acute medical or surgical care, but it clearly lacks a comprehensive approach, including psychological support, gerontological social care, and a wide range of community resources that can be delivered at doorstep rather than at the in-patient setting $[9,11]$.

\section{References}

1. Nikolich-Zugich, J., Knox, K.S., Rios, C.T., Natt, B., Bhattacharya, D., Fain, M.J. (2020) SARS-CoV-2 and COVID19 in older adults: what we may expect regarding pathogenesis, immune responses, and outcomes. GeroScience.

2. Pelicioni, P.H.S., Lord, S.R. (2020) COVID-19 will severely impact older people's lives, and in many more ways than you think! Brazilian J. Phys. Ther.

3. Al-Jabir, A., Kerwan, A., Nicola, M., Alsafi, Z., Khan, M., Sohrabi, C., O’Neill, N., Iosifidis, C., Griffin, M., Mathew, G., 
Agha, R. (2020) Impact of the Coronavirus (COVID-19) pandemic on surgical practice - Part 1. Int. J. Surg.

4. Mazumder, H., Hossain, M.M., Das, A. (2020) Geriatric Care during Public Health Emergencies: Lessons Learned from Novel Corona Virus Disease (COVID-19) Pandemic. J. Gerontol. Soc. Work.

5. Hossain, M.M., Mazumder, H., Tasnim, S., Nuzhath, T., Sultana, A. (2020) Geriatric Health in Bangladesh during COVID-19: Challenges and Recommendations. J. Gerontol. Soc. Work 1-4.

6. Lafortune, C., Huson, K., Santi, S., Stolee, P. (2015) Community-based primary health care for older adults: a qualitative study of the perceptions of clients, caregivers and health care providers. BMC Geriatr. 15, 57.

7. Siegler, E.L., Lama, S.D., Knight, M.G., Laureano, E., Carrington Reid, M. (2015) Community-Based Supports and Services for Older Adults: A Primer for Clinicians.
8. Shepperd, S., Iliffe, S. (1998) The effectiveness of hospital at home compared with in-patient hospital care: A systematic review. J. Public Heal. (United Kingdom) 20, 344-350.

9. de Sousa Vale, J., Franco, A.I., Oliveira, C. V., Araújo, I., Sousa, D. (2020) Hospital at Home: An Overview of Literature. Home Health Care Manag. Pract. 32, 118-123.

10. Stevenson, R., Angus, R., Blanchard, M., Bott, J., CollinsGilchrist, C., Davison, A., Ford, K., Fuld, J., Johnson, M., O'Kelly, N., O'Reilly, J., Redden-Rowley, K., Scullion, J., Sherrington, R., Taylor, S., Vaughn, P., Williams, J. (2007) Intermediate care - Hospital-at-Home in chronic obstructive pulmonary disease: British Thoracic Society guideline. Thorax 62, 200-210.

11. Watkins, L., Hall, C., Kring, D. (2012) Hospital to home: A transition program for frail older adults. Prof. Case Manag. 17, $117-123$.

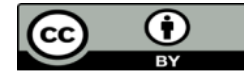

This work is licensed under Creative Commons Attribution 4.0 License

\section{To Submit Your Article Click Here: Submit Manuscript}

DOI: $10.31579 / 2693-4779 / 020$
Ready to submit your research? Choose Auctores and benefit from:

* fast, convenient online submission

* rigorous peer review by experienced research in your field

* rapid publication on acceptance

* authors retain copyrights

* unique DOI for all articles

* immediate, unrestricted online access

At Auctores, research is always in progress.

Learn more www.auctoresonline.org/journals/clinical-research-andclinical-trials 